\title{
Cristal: aspectos do tratamento pianístico no samba de Cesar Camargo Mariano
}

\author{
Rafael Tomazoni Gomes (UDESC, Florianópolis, SC) \\ rafaeltomazoni@hotmail.com
}

Guilherme A. Sauerbronn de Barros (UDESC, Florianópolis, SC)
guisauer@gmail.com

Resumo: Estudo sobre aspectos do tratamento pianístico do pianista e compositor Cesar Camargo Mariano em Cristal, registrada no álbum Solo Brasileiro, de 1994. Uma análise da conjunção entre "estruturas musicais afro-brasileiras" (OLIVEIRA PINTO, 2001) e a abordagem textural da escrita pianística revela uma síntese ou estilização da formação instrumental dos grupos populares. A prática do samba para piano remete à tradição dos chamados pianeiros, na qual Cesar Camargo Mariano se insere.

Palavras-chave: Cesar Camargo Mariano; o piano no samba; pianeiros da música popular brasileira.

\section{Cristal: aspects of the pianistic treatment in Cesar Camargo Mariano's samba}

Abstract: Study about the pianistic treatment by Brazilian composer and pianist Cesar Camargo Mariano in Cristal, recorded on the album Solo Brasileiro (1994). Pairing "Afro-Brazilian musical structures" (OLIVEIRA PINTO, 2001) with a textural approach of pianistic writing, we observe a synthesis and stylization in the musical formation of popular groups. The practice of the piano samba refers to the tradition of the so-called pianeiros, a tradition Cesar Camargo Mariano belongs to.

Keywords: Cesar Camargo Mariano; the piano in samba; pianeiros in Brazilian popular music.

\section{1 - 0 piano e o samba}

0 samba para piano é uma prática musical que remete ao final do século XIX e início do século XX através da atuação dos chamados pianeiros ${ }^{1}$, cujo repertório contemplava gêneros musicais característicos do "estilo antigo do samba" (SANDRONI, 2001, p.131), como o maxixe, a polca-lundu, o tango brasileiro e outros. Dentre o diversificado contexto de atuação profissional dos pianeiros, que incluia as salas de espera de cinema, lojas de partituras, teatro de revista, recitais e outros locais, sendo que o presente estudo destaca o contexto de baile, de música para dançar.

José Ramos Tinhorão nos relata um exemplo da atuação dos pianeiros no ambiente de baile, através de uma citação da pesquisadora Marisa Lira: "A animação dos bailecos [...] dependia da música. Se havia [...] dinheiro contratava-se um choro e, se o dono da casa estava [...] sem dinheiro, um pianeiro de ouvido" (Marisa Lira, citado por TINHORÃO 2005, p.198). Contratar um pianeiro era uma alternativa financeira em relação ao grupo instrumental de choro (geralmente violão, flauta e cavaquinho).
Um outro exemplo também é dado pela autora:

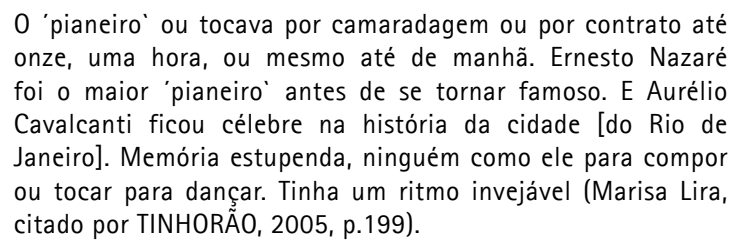

0 'pianeiro' ou tocava por camaradagem ou por contrato até onze, uma hora, ou mesmo até de manhã. Ernesto Nazaré foi o maior 'pianeiro' antes de se tornar famoso. E Aurélio Cavalcanti ficou célebre na história da cidade [do Rio de Janeiro]. Memória estupenda, ninguém como ele para compor ou tocar para dançar. Tinha um ritmo invejável (Marisa Lira, citado por TINHORÃO, 2005, p.199).

De acordo com a citação acima, a atividade de "compor ou tocar para dançar" exigia certas qualidades rítmicas da música do pianeiro: "um ritmo invejável", além de resistência física para conduzir um baile "até de manhã". Aurélio Cavalcante e Ernesto Nazareth (1863-1934) são citados como pianeiros que tinham tais habilidades em alto $\mathrm{grau}^{2}$.

Segundo Cacá Machado, "Nazareth escrevia sob o signo dos gêneros sincopados, o que satisfazia o gosto popular dos dançarinos de sua época" (MACHAD0, 2007, p.61). Sendo uma música que se presta à dança, considera-se o aspecto rítmico um elemento de central importância. 
Ao consultar um conjunto de polcas e tangos de Ernesto Nazareth, a ênfase no ritmo é facilmente percebida pela ocorrência de padrões ritmicos no acompanhamento relativamente constantes, mantidos do início ao final das peças. A polca-maxixe Atrevidinha do mesmo compositor, do ano de 1889, é um exemplo típico (Ex.1):

0 padrão rítmico da "síncope característica", termo cunhado por Mário de Andrade (SANDRONI, 2001, p.29), é mantido de maneira estável ao longo peça ${ }^{3}$ e pode ser observado na figuração rítmica da mão esquerda (Ex.1). Trata-se de um padrão típico do "paradigma do tresillo" (SANDRONI, 2001, p.28), que corresponde a uma série de variações rítmicas predominantes no estilo antigo do samba (maxixe, polca, tango brasileiro e outros).

Como observa José Ramos Tinhorão, Ernesto Nazareth "estilizou o ritmo do maxixe, sintetizado pelos conjuntos de choro a partir da polca e do lundu [...], [transportando] para o piano o novo estilo de interpretação que os chorões populares Ihe entregavam pronto" (TINHORÃO, 1974, p.65). Nesta perspectiva de redução ou estilização pianística da formação instrumental popular, a linha melódica de Atrevidinha (Ex.1) pode ser considerada análoga à linha melódica realizada pela flauta, e as estruturas realizadas na mão esquerda são análogas ao acompanhamento rítmico-harmônico realizado pelo violão ou cavaquinho. Cacá Machado reforça este argumento:

A solução formal que Nazareth encontrou para a estilização desses instrumentos tornou-se um paradigma para a escrita pianistica, porque traz a sonoridade dos instrumentos estilizados (tanto na montagem dos acordes como em sua função ritmica e intenção fraseológica) sem perder a especificidade da sonoridade do piano (MACHADO, 2007L, p.162).

A redução orquestral do grupo instrumental popular pelo piano também foi notada por Almeida: "como instrumento intérprete de choros ${ }^{4}$ o piano atuou como uma redução do grupo chorão, podendo realizar - à sua maneira - a melodiosidade da flauta, as harmonias, os baixos dos violões e a rítmica do cavaquinho" (ALMEIDA, 1999, p.105) e também por Rafael dos Santos: "a parte de piano solo de um choro funciona como uma redução orquestral, apresentando vários desafios para o compositor que deseja preservar tais elementos, resultando em obras de dificuldade técnica considerável [...]" (SANTOS, 2002, p.6). Para o pianista Leandro Braga, "nenhum ritmo, seja qual for, nasceu do piano. Estamos sempre imitando os instrumentos de percussão, tomando emprestado seus toques para criarmos os nossos" (BRAGA, 2003, p.8).

Como será visto em Cristal, este procedimento de redução, sintese ou estilização dos instrumentos caracteristicos dos grupos populares ao piano, bem como a manutenção de padrões rítmicos característicos do samba ao longo do discurso musical são fatores em comum entre a música dos chamados pianeiros e o tratamento pianístico praticado por Cesar Camargo Mariano.

\section{2 - Cesar Camargo Mariano}

Nascido no dia 19 de setembro de 1943, Cesar Camargo Mariano teve em sua infância um intenso contexto musical familiar promovido por seus pais. Como relata o próprio artista em seu livro de memórias (MARIANO, 2011), Wlademiro Camargo, o pai, tinha formação pianistica tradicional e costumava ouvir a música de Ernesto Nazareth e Chiquinha Gonzaga (1847-1935). Sua mãe, Maria Elisabeth de Camargo Rangel, costumava escutar emissoras de rádio locais e tinha preferência pela música norte-americana como, por exemplo, os cantores Tony Bennett, Bing Crosby e Frank Sinatra.

Wlademiro e Maria Elizabeth foram responsáveis por transformar sua casa num ambiente propício para o encontro de músicos que vinham se apresentar na cidade de São Paulo a partir do início de 1950. A postura Cesar Camargo Mariano, como espectador atento desses encontros, foi de central importância para sua formação

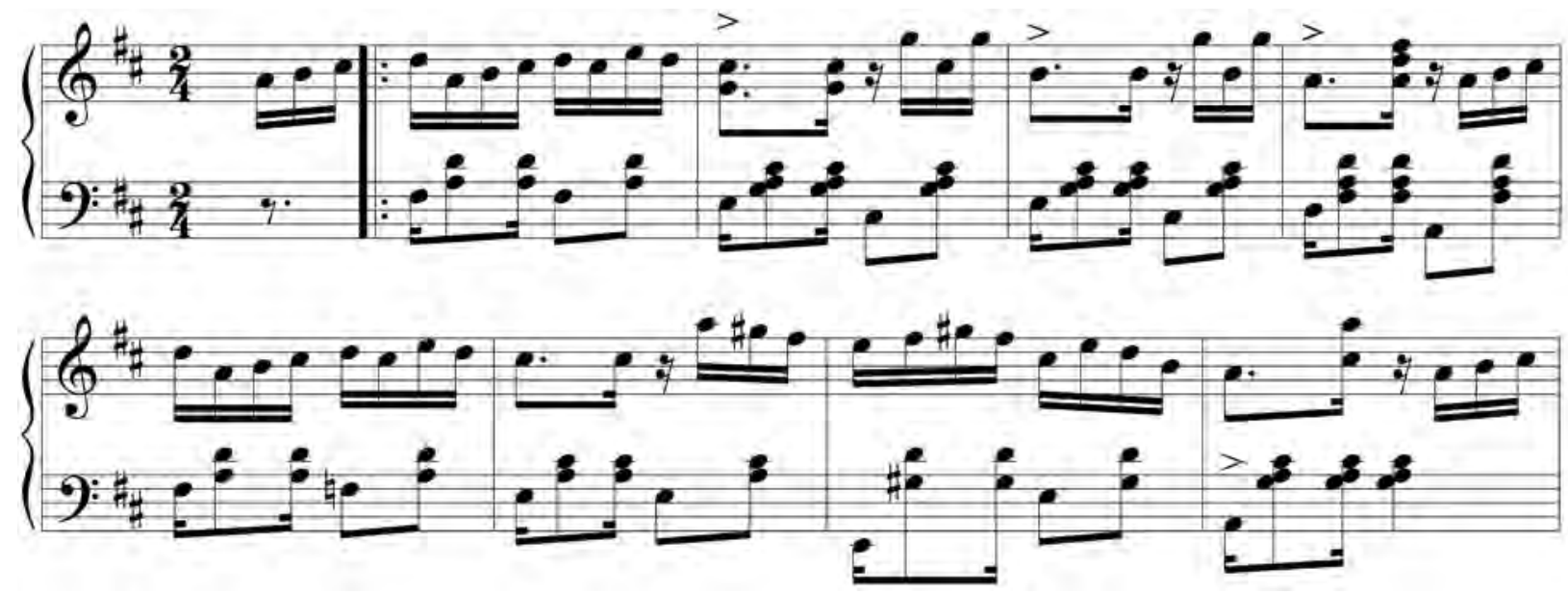

Ex.1 - Atrevidinha, Ernesto Nazareth 
musical ainda quando criança:

\begin{abstract}
[...] eu, com seis anos na época, comecei assim a ser iniciado na melhor tradição da música brasileira. Cada dia, o regional [do músico Maurício Moura] aparecia com algum artista que estava se apresentando na cidade: num dia, foi a Inezita Baroso [n.1925]; no outro, Jacob do Bandolim [1918-1969], aquela enciclopédia da música popular brasileira que retornaria sempre a nossa casa, toda vez que vinha a São Paulo fazer shows. Como os demais, vinha sem avisar. A casa do careca estava 24 horas aberta para a música (MARIANO, 2011, p.39).
\end{abstract}

No dia 19 de setembro de 1956, Cesar Camargo Mariano ganhou um piano de seus pais como presente pelo seu aniversário de 13 anos de idade. A partir de então, em seu contato diário com o instrumento, seguiu seus estudos como autodidata, compondo, criando exercícios para desenvolver o dedilhado, interpretando o repertório jazzístico e tendo a audição de discos como principal referência. Segundo o próprio pianista, "[uma das referências musicais eram os] trios na época do Oscar Peterson, Bill Evans, George Shearing, os trios todos, desde moleque que eu ouço. Então isso era a base [referência], e é até hoje [...]"5.

0 início da vida profissional foi como pianista de jazz na noite paulistana, atuando principalmente na formação em trio de piano, baixo e bateria, em estabelecimentos como as boates Lancaster, Baiúca e Juão Sebastião Bar.

\section{1 - Do jazz ao samba}

Cesar Camargo Mariano relata um episódio ocorrido na boate Baiúca, um momento representativo do processo de inclusão do samba no seu repertório, até então estritamente jazzístico:

De uma das mesas, me pediram que tocasse um 'sambinha'. Eu nunca havia tocado samba como os que tocavam nas rádios. Tocava choros e chorinhos, mas não era isso que aquela pessoa estava querendo ouvir. Alguns dos poucos temas brasileiros que eu tocava tinham acentuações em $4 \times 4$, quer dizer, uma 'pronúncia' jazzística. Na quarta vez que me pediram a mesma coisa, já com o Heraldo [proprietário da Baiúca] me olhando feio, começamos a tocar o tal do samba, que não lembro qual era, comigo marcando o ritmo, com a mão esquerda, no tempo forte - pam, pam, pam, pam - como fazia Errol Garner (sic), um dos meus grandes idolos do jazz" (MARIANO, 2001, p.97).
Neste período Cesar Camargo Mariano estava com aproximadamente dezessete ou dezoito anos de idade, em plena fase de "jazzista radical", e gostava de tocar "imitando" o pianista norte americano Erroll Garner (1923-1977). Em relação a este pianista, Mark C. GRIDLEY (2005, p.112) e pianista Dick Hyman ${ }^{6}$, descrevem aspectos gerais de seu estilo pianístico. 0 exemplo abaixo traz um trecho de Teach me tonight, interpretada por Erroll Garner na formação de trio, no ano de 1954, representativo do estilo que influenciou Cesar Camargo Mariano:

0 tratamento melódico ocorre através de blocos de acordes, onde as notas da linha melódica são dobradas pelo intervalo de oitava e "preenchidas" por outras notas, comparadas por Dick Hyman ao naipe de metais da formação de big band; e a mão esquerda, associada ao acompanhamento guitarrístico, é caracterizada por acordes em semínimas na região médio grave, e correspondem às acentuações jazzísticas no compasso quaternário, ao qual se refere Cesar Camargo Mariano na citação anterior.

Ao ser intimado a tocar um "sambinha", Cesar Camargo Mariano lançou mão do que Ihe era familiar, o estilo Erroll Garner, um procedimento que fazia parte do seu cotidiano de músico jazzista. Portanto, o resultado foi um "sambinha" ao estilo Erroll Garner:

Ficou jazz demais. Eu não estava gostando, ninguém estava gostando - para eles, aquilo não era samba, nem bossa nova, nem jazz. Sabá [contrabaixista] olhava torto pra mim. Resolvi então mudar a acentuação da mão esquerda, passando a acentuar o tempo fraco - 1-pam, 2-pam, 3-pam, 4-pam, e saiu um jeito meio up-beat que me agradou. Sabá piscou para mim, sorrindo; Heraldo, encostado no bar, fez um sinal de positivo com o polegar; e o moço que pediu 'um sambinha', lá da mesa, discretamente me agradeceu. Passei a tocar samba assim (MARIANO, 2011, p.97).

A solução encontrada pelo pianista, no "calor do momento", foi passar as semínimas da mão esquerda para o contratempo, o que corresponde à segunda e a quarta semicolcheias de cada tempo, uma técnica que se tornou recorrente na obra de Cesar Camargo Mariano, principalmente na década de 1960 com os trios. Um exemplo desta aplicação (Ex.3) é a faixa Berimbau

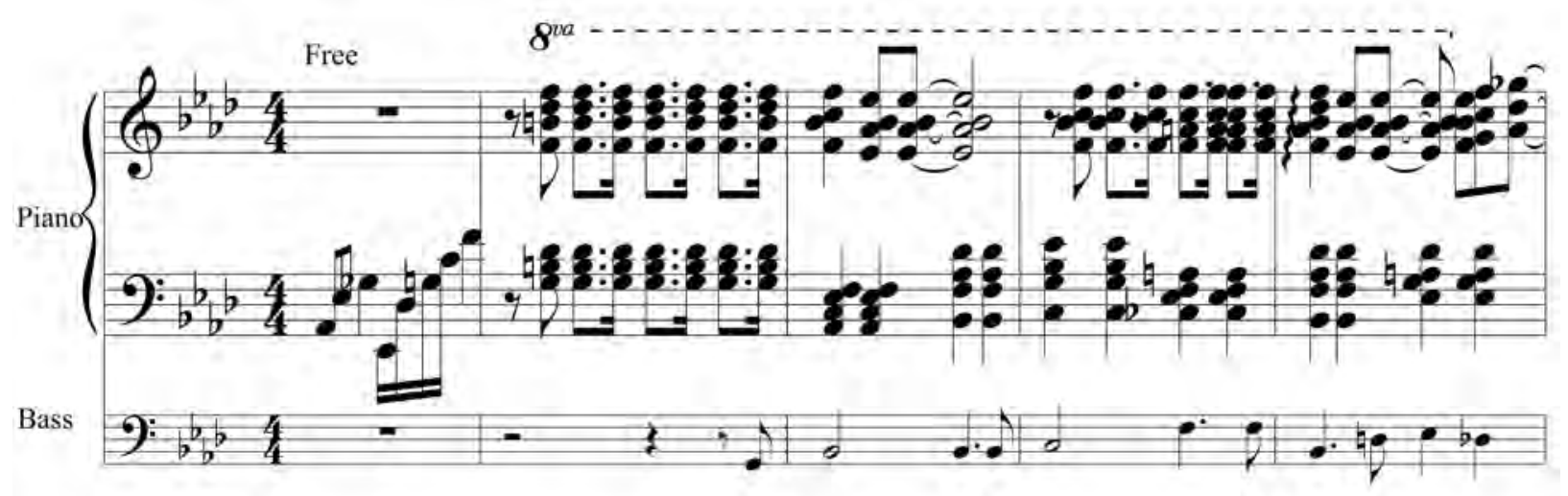

Ex.2 - Teach me Tonight, de Erroll Garner, cujo estilo influenciou Cesar Camargo Mariano? 


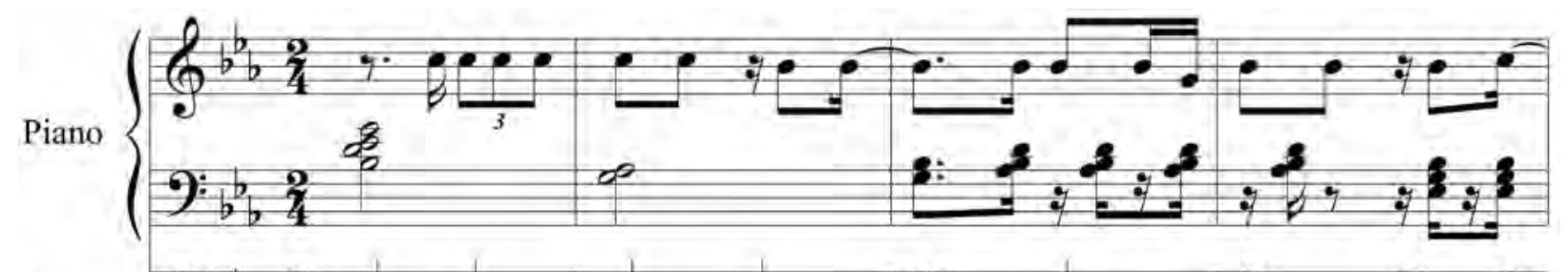

Baixo
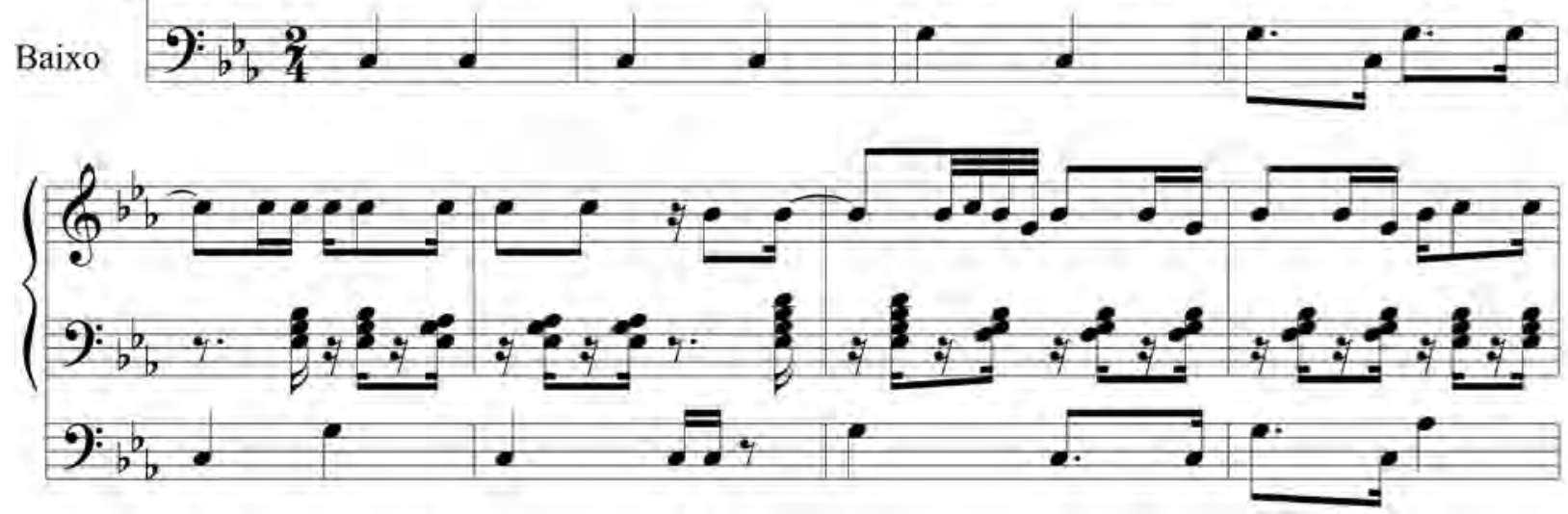

Ex.3 - Berimbau - acompanhamento na mão esquerda que valoriza a segunda e a quarta semicolcheia de cada tempo.

(Baden Powel \& Vinícius de Moraes) gravada em 1964 no disco Sambalanço Trio Vol I, cujo grupo era formado pelo pianista Cesar Camargo Mariano, pelo contrabaixista Humberto Clayber e pelo baterista Airto Moreira.

Como pode ser observado no Ex.3, o padrão rítmico adotado pelo acompanhamento na mão esquerda diferentemente do exemplo de Erroll Garner (Ex.2) - é totalmente contramétrico, pois os acordes são localizados no contratempo, "um jeito meio up-beat", como Mariano se refere na citação anterior. Tal padrão relaciona-se de forma complementar com as semínimas no baixo, que marcam o primeiro e segundo tempo. Somando-se esses dois padrões, tem-se a figuração semicolcheia - colcheia - semicolcheia, presente na música de Ernesto Nazareth, representante do estilo do samba antigo.

No exemplo Berimbau pelo Sambalanço Trio (Ex.3), o acompanhamento realizado por Cesar Camargo Mariano na mão esquerda segue um padrão ritmico relativamente estável, mantido ao longo desta seção formal da peça. A repetição de um determinado padrão rítmico no acompanhamento é um fator em comum entre Cesar Camargo Mariano e Erroll Garner. A estabilidade do padrão rítmico, repetido ao longo de frases ou seções estruturais de uma determinada peça, é fator que identificamos anteriormente como característica da música dos chamados pianeiros, associada neste estudo à dança, mais especificamente ao contexto de baile. Como será visto em Cristal, esse também é um traço estilístico do tratamento pianistico praticado por Cesar Camargo Mariano em seu repertório de sambas para piano solo.

A produção artística de Cesar Camargo Mariano na década de 1960, principalmente com o Sambalanço
Trio, enfatiza o gênero samba influenciado por sua formação jazzística. 0 episódio vivido na Baiúca marca o início do desenvolvimento do estilo pianístico do músico nesta nova forma de apresentação do samba, também referida como "bossa-nova tocada como instrumental" (FAOUR, 2006) ou "Samba-Jazz" (GOMES, 2010; SARAIVA, 2007).

Marcelo Silva Gomes sintetiza algumas características deste estilo de samba:

[...] a utilização de acordes acrescidos de tensões, substituições harmônicas, uso e sistematização da improvisação, instrumentação, técnicas de performance, manutenção de um dado ciclo harmônico e métrico (chorus) como sustentáculo à realização de frases melódicas e ainda [...] a possibilidade de rompimento com padrões celulares constantes (GOMES, 2010, p.45).

A partir de uma audição atenta dos discos gravados por Cesar Camargo Mariano junto ao Sambalanço Trio, podemos verificar a ocorrência dos aspectos listados por Marcelo Silva Gomes, com exceção do último aspecto, pois o pianista realiza padrões rítmicos constantes no acompanhamento da mão esquerda. Podemos atribuir tal traço estilístico (além da influência de Erroll Garner) à sua formação musical no contexto familiar, junto aos músicos de choro e ao contato com a música dos pianeiros. Segundo Cesar Camargo Mariano,

[...] por minha própria formação básica, desenvolvida entre chorões, até hoje sou alucinado pelo gênero. Sabá, Toninho e eu, em todos os ensaios, quando tinha uma brecha, tocávamos choros, chorinhos, antigos ou novos, e eu brincava de modificar as harmonias originais, os andamentos... Vivia pesquisando e tocando choros de Ernesto Nazareth, Pixinguinha (que minha mãe adorava!), ouvindo direto Chiquinha Gonzaga (predileta do meu pai), de quem recebi grande influência como pianista, tocando samba (MARIANO, 2011, p.191). 


\section{2 - Música popular instrumental brasileira}

Parte da produção artística de Cesar Camargo Mariano publicada a partir da segunda metade da década de 1960, incluindo o disco Solo Brasileiro, também pode ser entendida como uma manifestação do gênero "música popular instrumental brasileira" (MPIB), termo adotado por PIEDADE (2005) e corroborado por CIRINO (2009). Dentre as características da prática da MPIB descritas por esses autores, o presente estudo destaca a manipulação de uma variedade de gêneros, ritmos ou estilos, que são dispostos lado a lado no discurso musical.

A partir do final da década de 1960, a música de Cesar Camargo Mariano assume uma pluralidade de tendências e gêneros musicais, que atravessam a década de 1970 (quando atuou basicamente como arranjador e pianista da cantora Elis Regina), e que na década de 1980 manifesta-se através de uma produção expressiva de MPIB. Intensificada pela pesquisa com teclados eletrônicos, esta produção foi registrada em álbuns como Samambaia (1981), Todas as Teclas (Ariola, 1984), Prisma (Pointer, 1985), Mitos (Sony, 1988), Ponte das estrelas (1988), Cesar Camargo Mariano (Chorus-Som Livre, 1989) e outros.

As músicas reunidas no disco Solo Brasileiro (Polygram, 1994), que contém a faixa Cristal, foram compostas por Cesar Camargo Mariano em um período posterior à sua produção de MPIB citada e também podem ser caracterizadas como tal. Seu samba para piano solo apresenta uma variedade de linhas, musicalidades e gêneros que emergem no seu discurso musical, e dialogam com o samba. Tal aspecto será observado mais adiante no presente estudo na seção de introdução de Cristal.

\section{3 - Ritmo e Textura}

A noção de síncope é considerada um elemento rítmico "emblemático" da música brasileira. Carlos Sandroni chama atenção para o "caráter culturalmente condicionado do conceito de síncope" (SANDRONI, 2001, p.21), tido pela musicologia tradicional como um desvio em relação à métrica "padrão". Tal ruptura em relação à regularidade da acentuação ocorre pela valorização dos contratempos (ALMEIDA, 1999), o que no samba é uma caracteristica de central importância.

Como observa o autor, muitos pesquisadores atribuem a origem da síncope ao continente africano, fato observado por Mário de Andrade como um "lugarcomum que não se funda sobre evidência documental sólida" (SANDRONI, 2001, p.23). Independentemente de sua origem (músicas primitivas de portugueses, espanhóis, africanos ou ameríndios, como observa Mário de Andrade $^{8}$ ), a ocorrência da síncope - que sob a ótica da música de tradição escrita ocidental caracteriza a contrametricidade - possibilita o estabelecimento de paralelos entre formas rítmicas do samba e da música africana, o que leva Sandroni a constatar que, neste ponto, "o Brasil está muito mais perto da África do que da Europa" (SANDRONI, 2001, p.25).

Um exemplo desta aproximação é a pesquisa de Kazadiwa Mukuna ${ }^{9}$ sobre elementos bantu na música popular brasileira, onde o autor identifica no samba padrões rítmicos encontrados na música de algumas regiões do Zaire. Ao constatar no campo da musicologia africana uma série de aspectos musicais em comum com o samba, Carlos Sandroni conclui que "parece pois legítimo supor que elas fazem parte de uma herança musical trazida do Continente Negro, mesmo se o contexto e o sentido de tal herança se transfiguraram enormemente" (SANDRONI, 2001, p.25).

Considerando o ambiente de formação musical e atuação profissional de Cesar Camargo Mariano, é evidente que o sentido e o contexto de tal herança são outros. Porém, sendo o samba considerado uma manifestação musical afro-brasileira, podemos nos valer de alguns conceitos desenvolvidos por autores cujos trabalhos remetem à rítmica da música africana. 0 etnomusicólogo Tiago de Oliveira Pinto, em seu artigo "As cores do som: estruturas sonoras e concepção estética na música afro-brasileira", propõe uma sistematização de estruturas musicais afro-brasileiras com base em estudos feitos no campo da musicologia africana e brasileira (OLIVERIA PINTO, 2001).

Procurando entender a música como configuração sonora no tempo (aspecto rítmico), Oliveira Pinto desprendese do pensamento ocidental que prevê a organização rítmica pela lógica da métrica do compasso, com seus tempos fortes e fracos (OLIVEIRA PINTO, 2001). Segundo Carlos Sandroni, essa perspectiva de ruptura também é adotada por outros estudiosos da música africana, como Simha Arom e Gehrard Kubik, que aboliram a palavra síncope de seu vocabulário, pois consideram o conceito de síncope uma abstração decorrente da escrita musical ocidental (SANDRONI, 2001, p.27). A noção de síncope seria, portanto, estranha ao fazer musical afro-brasileiro. No sistema de notação rítmica adotado por Oliveira Pinto, uma vez abolida a métrica e as barras de compasso, os conceitos de contratempo, contrametricidade e síncope são desconsiderados.

Apresentaremos a seguir alguns conceitos introduzidos por OLIVEIRA PINTO (2001), elaborados pelo autor a partir dos instrumentos de percussão utilizados pelas escolas de samba, bem como considerações sobre a adaptação destes conceitos ao tratamento pianístico.

\section{1 - Pulsação elementar}

Segundo Oliveira Pinto, a pulsação elementar corresponde à menor unidade de tempo que preenche a sequência musical (OLIVEIRA PINTO, 2001, p.92). De acordo com o autor, 16 pulsos elementares apoiam a linha rítmica do samba, cujas articulações sonoras caem necessariamente sobre esses pulsos (Ex.4). 


\section{2 - Marcação}

Outro elemento musical trazido à tona por Oliveira Pinto é a marcação, a "batida fundamental e regular, que caracteriza o sobe e desce rítmico do samba" (OLIVEIRA PINTO, 2001, p.93). Com função de referência para o tempo, é executada por dois surdos de tamanhos diferentes, o surdo (surdo 1) e o contra-surdo (surdo 2), sendo que o segundo tem sonoridade mais grave. Em relação à pulsação elementar, o autor representa a marcação da seguinte forma (Ex.4):

(16) $\ldots \ldots \ldots \ldots \ldots$ pulsação elementar

(16) $\mathbf{x} \ldots \ldots \mathbf{x} \ldots \ldots \ldots$ marcação surdo 1

(16) $\ldots . \times \mathbf{x} \ldots \ldots \times \mathbf{x} \ldots$ marcação surdo 2

Ex.4 - Pulsação elementar e marcação de dois surdos no samba.

Uma característica importante na marcação do ritmo do samba realizada pelo surdo é o apoio no segundo tempo e uma nota com curta duração no primeiro tempo que, numa combinação da escrita rítmica convencional com a notação rítmica utilizada pelos africanistas, pode ser representado da seguinte maneira (Ex.5):

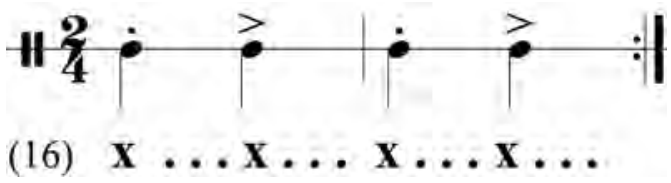

Ex.5 - Marcação básica do surdo.

De acordo com BOLÃO (2003, p.28), nos bailes de carnaval é comum a utilização de dois surdos por um único músico percussionista, sendo que o mais agudo marca o primeiro tempo e o mais grave o segundo tempo. 0 autor apresenta diversos exemplos de variações de frases ritmicas realizadas por esses instrumentos, sendo que dois exemplos são expostos abaixo (Ex.6):

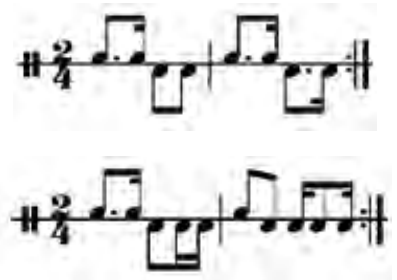

Ex.6 - Variações de frases rítmicas realizadas por dois surdos.

\section{3 - Linha rítmica ou linha-guia (time-line)} Introduzido por Joseph K. Nketia em 1970, o termo timeline refere-se a padrões ritmicos que servem como "linha guia" (SANDRONI, 2001, p.25). Oliveira Pinto observa que geralmente a linha-guia é sonorizada com tom alto ou agudo e penetrante, de modo que seja ouvida pelo grupo como uma espécie de metrônomo, uma orientação sonora que possibilita a coordenação geral em meio a uma variedade de eventos rítmicos concorrentes. $\mathrm{Na}$ escola de samba, é sobretudo o tamborim o instrumento de percussão responsável por realizar esta fórmula. 0 exemplo seguinte traz o padrão do tamborim, também apresentado por Oliveira Pinto, e pode ser observado numa combinação de ambos sistemas de escrita (Ex.7):

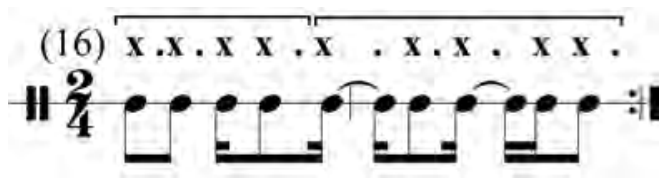

Ex.7 - Padrão do tamborim em ambos sistemas de escrita rítmica.

Trata-se de uma fórmula cujas articulações sonoras (x) e complementares (.) são organizadas de forma assimétrica, uma vez que as 16 pulsações organizam-se em $7+9$ (como indicam os colchetes no Ex.7) e ainda podem ser subdividas em $[2+2+(1+2)]+[2+2+2+(1+2)]$. Simha Arom chama esse fenômeno de "imparidade ritmica" (citado por SANDRONI, ibid. p.25), pois as 16 pulsações elementares não são organizadas em pares de $8+8$, ou $4+4+4+4$ (equivalente às semínimas do compasso binário). Sob a lógica das divisões pares da escrita ocidental (semibreves em mínimas, mínimas em semínimas e assim por diante), a imparidade rítmica caracteriza uma escrita contramétrica. Variações rítmicas nesses moldes são denominadas "paradigma do Estácio" (SANDRONI, 2001, p.32), e são característicos do estilo novo do samba, posteriores à década de 1920 .

\section{4 - Relação de complementaridade ou interlocking}

A relação de complementaridade ou interlocking sonoro (Kubik, citado por OLIVEIRA PINTO, 2001, p.101) é outro aspecto do fazer musical das escolas de samba descrito por Oliveira Pinto. Segundo o autor,

\footnotetext{
[...] quando dois ou três músicos intercalam os pulsos de seus padrões rítmicos de forma regular, levando assim a uma complementaridade das diferentes partes tocadas. Este intercalar dos impulsos é aspecto tão constitutivo da música africana e afrobrasileira, que acontece inclusive na forma como a mão direita e a esquerda se complementam ao percutirem um tambor, ao tocarem uma marimba (OLIVEIRA PINTO, 2001, p.101).
}

0 exemplo da forma como mão direita e mão esquerda se complementam ao percutirem um tambor, é ilustrativo da relação de complementaridade entre as mãos do pianista, aspecto notado por Cacá Machado em relação a uma determinada passagem musical da obra de Ernesto Nazareth, onde o autor afirma que o "suingue do maxixe realiza-se nessa complementaridade das mãos" 


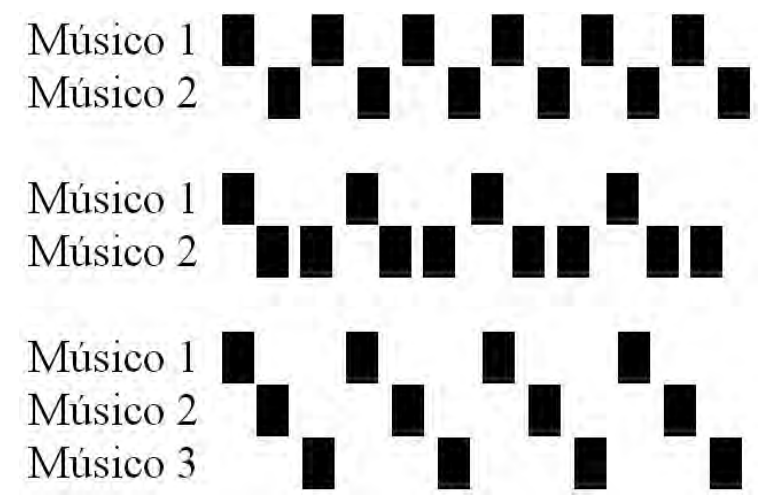

Ex.8 - Diferentes padrões de interlocking sonoro.

(MACHAD0, 2007, p.126). Nestes casos, os impactos de uma linha sonora se encaixam nos momentos vagos deixados pela outra e vice versa. 0 Ex.8 é uma representação de Kubik para o interlocking sonoro (citado por OLIVEIRA PINTO, 2001, p.101):

A relação de complementaridade ou interlocking entre as diferentes partes tocadas por dois ou três músicos é análoga à relação entre as diversas camadas texturais na escrita pianística. Tal aspecto será verificado no presente estudo, na seção B de Cristal (Ex.15 e 16).

A descrição do fenômeno musical realizada pelos estudiosos que tratam da música africana e afro-brasileira, cujas referências encontramos nos textos de Carlos SANDRONI (2001) e OLIVEIRA PINTO (2001), oferecem, portanto, um corpo de terminologias e processos musicais relevantes para se pensar o tratamento pianístico no samba, como as noções de pulsação elementar, marcação, imparidade rítmica, linha guia (time-line), e relação de complementaridade ou interlocking.

\section{5 - Resultante rítmica}

0 padrão rítmico que resulta da soma dos padrões individuais de cada instrumento - no caso do piano, de cada camada textural - será denominado resultante rítmica. Trata-se de um sistema de notação em que os padrões rítmicos de cada camada textural, que na textura pianística ocorrem em planos diferentes, são dispostos simultaneamente num único plano horizontal. Através da resultante rítmica, é realizada a redução de uma determinada trama de eventos rítmicos a uma única linha, que tem como objetivo a representação de uma sintese rítmica de um determinado trecho musical, a fim de observar um ou mais padrões ritmicos que sustentam o samba ao longo de uma frase ou seção da composição.

$\mathrm{Na}$ resultante ritmica, as acentuações das pulsações elementares são dispostas em três níveis hierárquicos: linha-guia, marcação e padrão complementar. Um exemplo da caracterização e reconhecimento da resultante rítmica é dado a partir da representação rítmica do c.17 de Cristal (Ex.9):

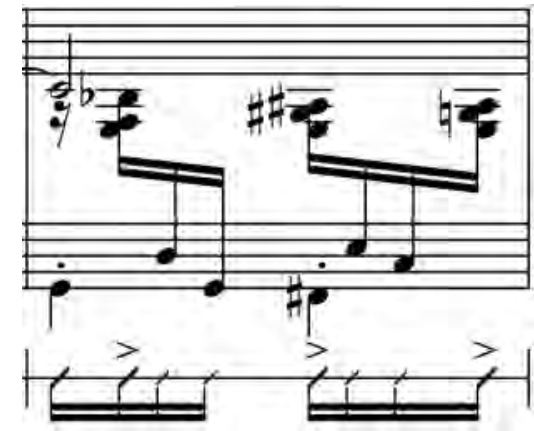

Ex.9 - Cristal, resultante rítmica do c.17.

0 preenchimento das 8 pulsações elementares é representado no compasso $2 / 4$ por um continuum de semicolcheias cujas acentuações podem ser pensadas hierarquicamente em três niveis: 1) As notas grafadas com o sinal de acento representam a linha-guia (time-line), no grau mais elevado da hierarquia. 2) A primeira nota de cada tempo, grafada em tamanho natural sem o sinal de acento, representa a marcação do baixo, análoga ao tambor-surdo. Não raro, a linhaguia ocupa a mesma posição específica da marcação (mesma pulsação elementar), como no Ex.9 acima, onde a segunda marcação do baixo (quinta semicolcheia do compasso) é localizada na mesma posição de uma nota da linha-guia. Neste caso, a notação desta posição corresponde à linha-guia. 3) As notas menores correspondem às pulsações complementares, pensadas como "notas fantasmas" ou "ghost notes"10 que, apesar de apresentarem o menor grau de relevância nesses níveis hierárquicos, são importantes para 0 preenchimento sonoro das pulsações elementares.

A notação da resultante rítmica leva em conta apenas o ataque dos sons segundo sua posição nas 8 ou 16 pulsações elementares, desconsiderando as durações das notas, uma vez que o objetivo deste sistema não é 
compreender aspectos da sonoridade pianística de Cesar Camargo Mariano, como detalhes de sua articulação, mas prover uma representação rítmica da textura pianística.

Sendo a partitura uma representação limitada do fenômeno musical, faz-se necessário o suporte do exemplo em áudio, trazendo o elemento sonoro como um parâmetro a ser considerado na análise. Sendo assim, o reconhecimento das acentuações que caracterizam a resultante rítmica são fundamentados em dados sensíveis, oriundos da escuta musical.

\section{4 - Cristal}

Como objetivo principal da análise de Cristal, destaca-se a verificação de como Cesar Camargo Mariano se insere na tradição dos pianeiros através da síntese ou estilização pianística dos instrumentos característicos de grupos populares. Ao mesmo tempo, serão apontados aspectos de seu tratamento pianístico no samba para piano solo. 0 disco Solo Brasileiro (1994) se apresenta como um dos mais representativos desta produção no conjunto de sua obra. 0 álbum, gravado em março de 1993 em Los Angeles, Estados Unidos, traz a seguinte declaração de Cesar Camargo Mariano: "Com este projeto, considero comemorados os meus 35 anos de carreira. Aliás, foi assim que tudo começou: - Tocando piano" (MARIANO, 1994).
0 critério de escolha da faixa Cristal é a hipótese de que nesta obra Cesar Camargo Mariano sintetiza os pilares de sua formação musical: o repertório clássicoromântico para piano (influência dos discos ouvidos em casa por seu pai), a música dos chamados pianeiros, 0 jazz e sua produção de MPIB.

Cristal apresenta forma ternária: Introdução; $A ; B$; introdução; $A ; B$; introdução. Cada seção formal apresenta características distintas em sua estrutura. 0 texto segue com a análise descritiva da obra, organizada de acordo com as seções formais, tendo a partitura transcrita por esta pesquisa como suporte para a análise.

\section{1 - Seção de introdução}

A linha-guia indicada pela resultante rítmica (Ex.10) é recorrente ao longo da seção de introdução e reforça o apoio na nota Dó 1, formando o padrão do tresillo $3+3+2$ - (SANDRONI, 2001, p.28), através do ciclo que se apresenta deslocado um quarto de tempo em relação às barras de compasso, pois as primeiras semicolcheias dos compassos não são preenchidas (representadas por pausas na resultante rítmica). No ciclo de 8 pulsações elementares, a representação da linha-guia é dada por "(8) . x . x . . x".
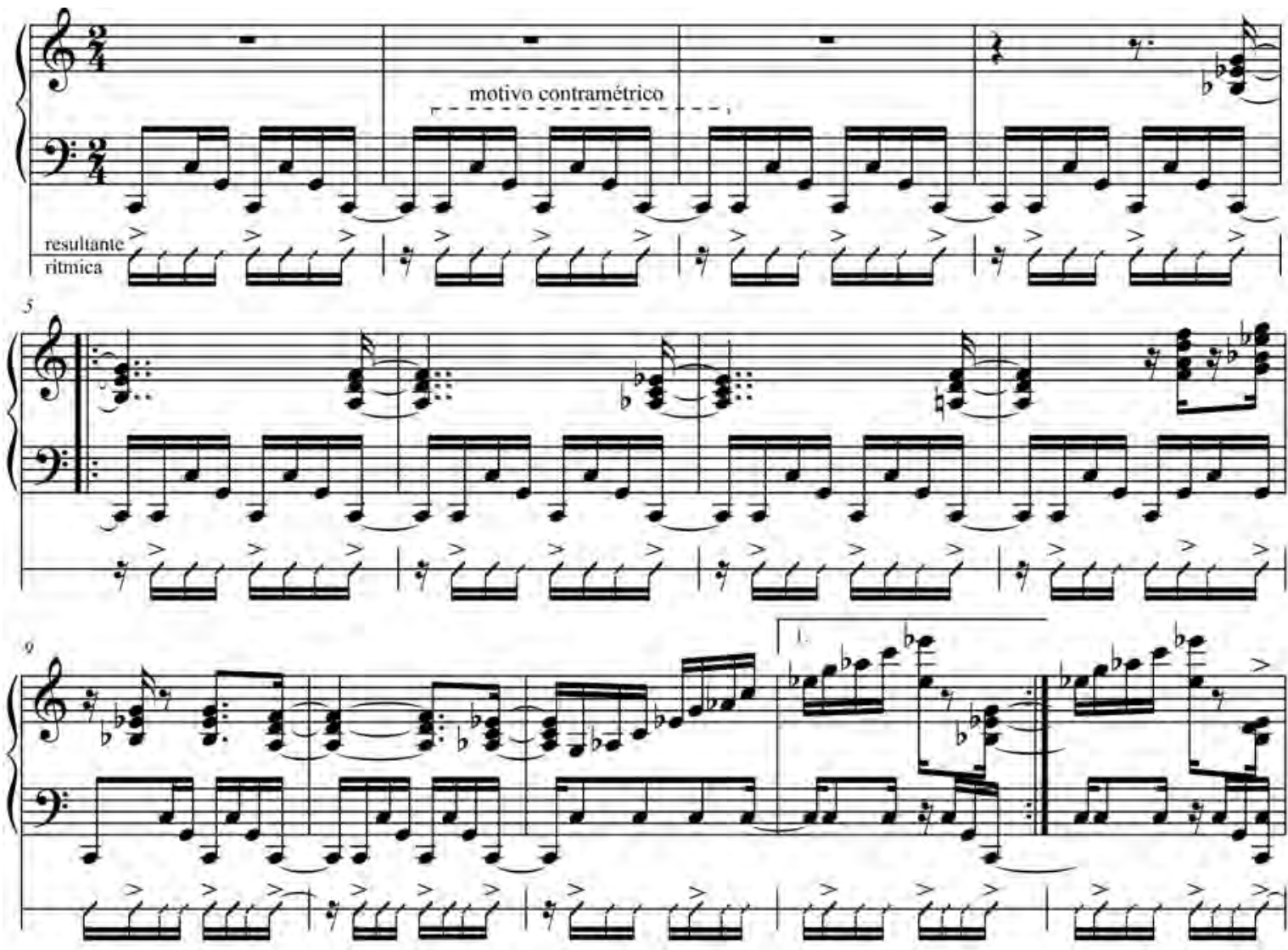

Ex.10 - Seção de introdução e representação da resultante rítmica. 
Apesar da indicação do gênero samba-choro na edição publicada por Samambaia Music ${ }^{11}$, esta linha de baixo está longe de ser associada à marcação do tambor-surdo característico do samba de acordo com a descrição dos aspectos musicais do samba realizada anteriormente. Portanto, percebe-se ainda nos quatro primeiros compassos que não é a intenção do compositor restringir-se aos traços considerados mais tradicionais do gênero. Essa hipótese é confirmada com a presença das triades na região média a partir do quarto compasso.

Formadas por empréstimo modal, as triades de Mi bemol, Ré menor e Lá bemol são conduzidas em forma de chord loop ${ }^{12}$ sobre o baixo pedal Dó, resultando em duas camadas texturais distintas que apresentam relativo grau de interdependência, por estarem no contexto da mesma linhaguia, valorizando a última semicolcheia dos compassos.
Esse ambiente de pouca movimentação harmônica, cujas características rítmicas não remetem diretamente ao samba, pode ser associado aqui à musicalidade fusion, ou seja, uma fusão ou diálogo com outros gêneros musicais como o funk e o pop, traço característico da chamada Música Popular Instrumental Brasileira (MPIB), que podemos associar à produção artística de Cesar Camargo Mariano posterior à década de 1970, marcada pelas experiências com teclados eletrônicos.

\section{2 - Seção A}

Na passagem para a seção $A$, ocorre uma ruptura textural acentuada, onde a densidade de eventos é reduzida a uma única linha melódica no c.14, ampliada para três camadas texturais a partir do c.15 (Ex.11). No entanto, tais mudanças texturais abruptas não interferem na linha-guia, que assume a função de "fio condutor" entre

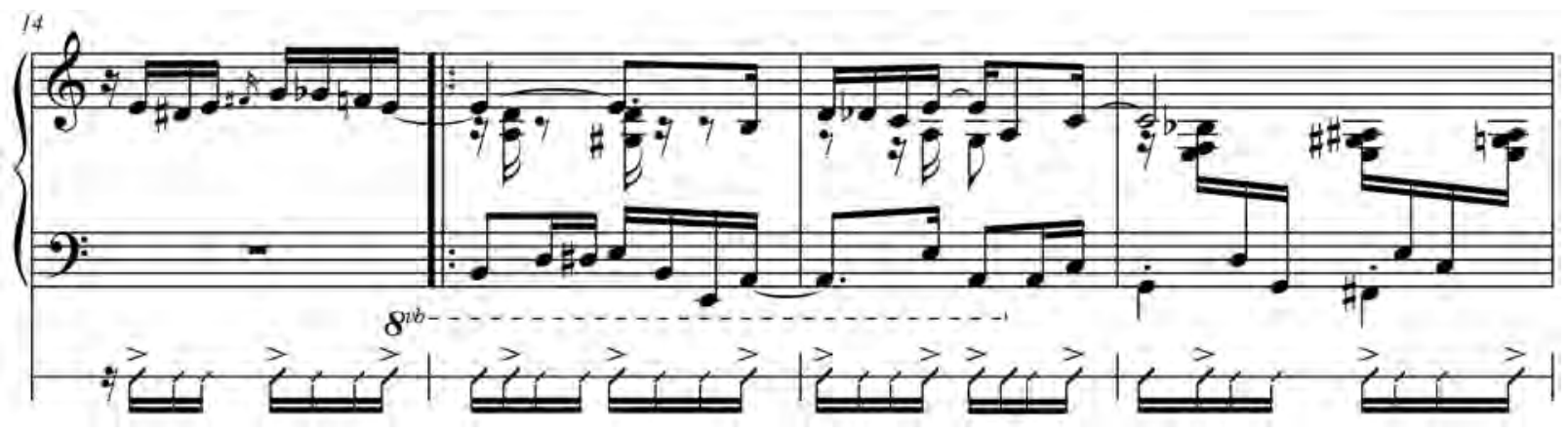

Ex.11 - Cristal, c.14-17: estabilidade da linha-guia.

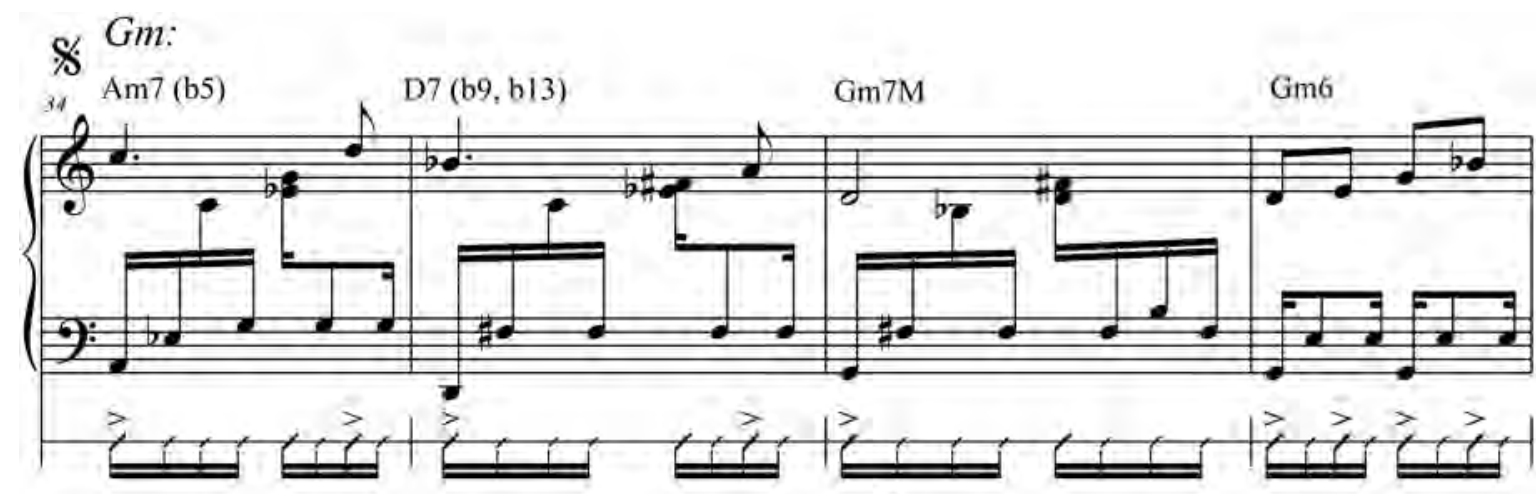

$G$ :

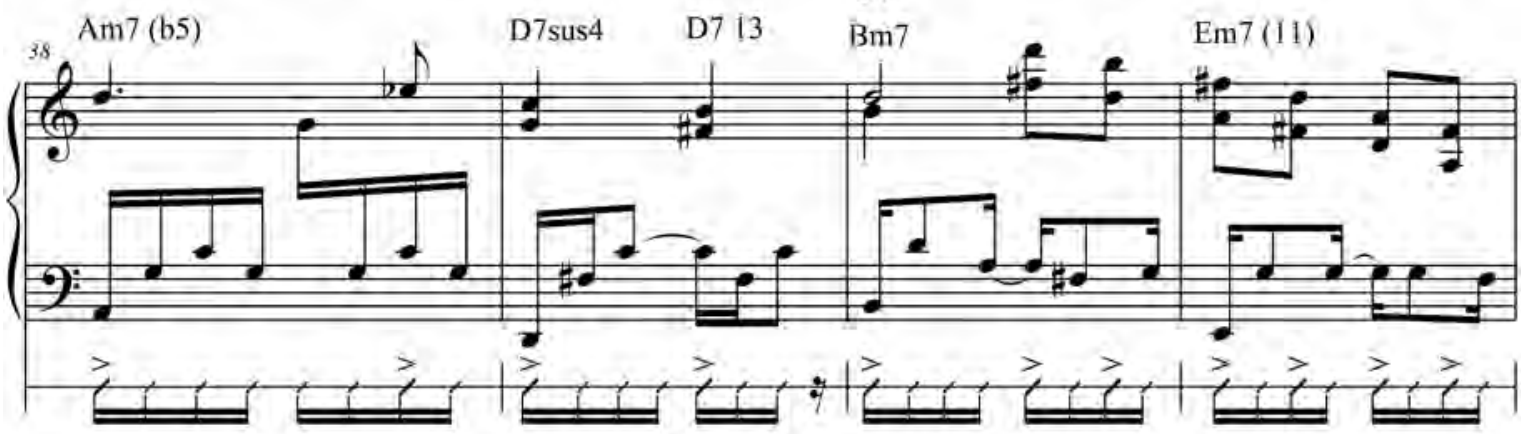

Ex.12 - Cristal, c.34-41: semelhança rítmica e textural com o repertório clássico-romântico. 
múltiplos tecidos musicais. A linha-guia é, portanto, um fator de estabilidade rítmica em meio a uma intensa instabilidade textural. Neste ponto, estabelecemos uma relação entre ritmo e textura.

Em sua interpretação musical, Cesar Camargo Mariano imprime a articulação non legato, onde as acentuações rítmicas aplicadas à linha melódica sugerem ou reforçam a própria linha-guia, caracterizando uma abordagem "rítmica" à interpretação melódica nesta seção, em oposição à primeira frase da seção B.

\section{3 - Seção B}

A seção B abrange os c.34-58, organizados em três frases de oito compassos, divididas por arpejos que ocorrem nos dois últimos compassos de cada frase.

\section{Primeira frase - c.34-41}

Trata-se de uma passagem contrastante na peça como um todo, onde as características rítmicas associadas à música afro-brasileira - como a lógica da imparidade rítmica na divisão das acentuações das pulsações elementares - são temporariamente abandonadas.

Ao contrário do restante da peça, nestes oito compassos não é possível verificar o aspecto rítmico característico do samba (Ex.12). Na notação da resultante rítmica, observa-se que as notas consideradas de maior grau de relevância na hierarquia das acentuações são as notas da melodia, cujo ritmo se encaixa perfeitamente na lógica da divisão par prevista pelo pensamento da escrita ocidental convencional, representada pelo compasso
2/4. Portanto, esta passagem apresenta uma escrita ritmicamente cométrica, onde predomina a acentuação dos "tempos fortes" do compasso, elemento que torna 0 trecho mais "europeu", do ponto de vista da semelhança com o repertório do classicismo, do romantismo e de toda uma tradição anterior da música europeia.

Tanto o continuum de semicolcheias quanto a relação de complementaridade entre as camadas texturais e a marcação do baixo estão presentes aqui, porém em outro contexto. Considerando a semelhança rítmica e textural com o repertório clássico-romântico, as semicolcheias da região intermediária podem ser pensadas como um artifício pianístico para simular o acompanhamento orquestral, onde as vozes são prolongadas ao longo do compasso. Esta hipótese é reforçada pela utilização do pedal direito do piano, toque legato e pela interpretação cantabile da linha melódica, fatores que encobrem o aspecto percussivo.

Outro aspecto contrastante desta passagem é o tratamento harmônico, que na primeira frase da seção B inicia um processo progressivo de afastamento da tonalidade principal (Dó maior) que, como veremos nas próximas páginas, alcança o máximo de afastamento na terceira frase, região de Dó bemol maior. Nos c.34-39 (Ex.12) predomina a região de Sol menor, e a partir do segundo tempo do c.39 com a nota Si natural, é sugerida a mudança para o modo maior, que é atingido no c.40-41 com os acordes Bm7 e Em7, respectivamente terceiro e sexto graus da tonalidade de Sol maior, região da dominante. Esta relação intervalar de quarta justa entre as fundamentais dos acordes será mantida nos compassos seguintes. A transição para a segunda frase ocorre com arpejos na mão direita, nos c.40-41.

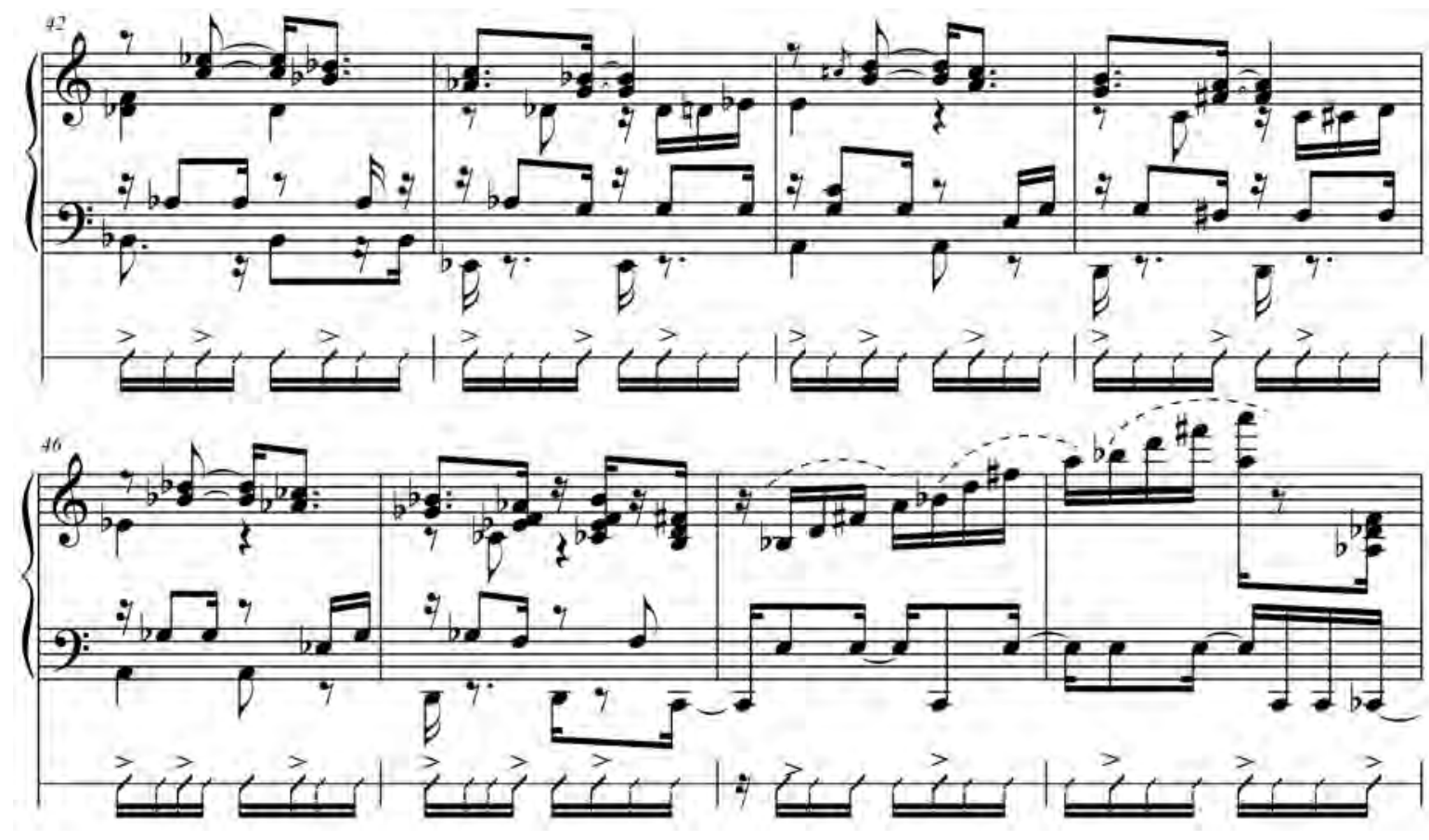

Ex.13 - Cristal, c.42-49 e representação da resultante rítmica. 
Segunda frase - c.42-49

A segunda frase da seção $B$, que abrange os c.42-49, marca o retorno dos elementos rítmicos do samba, como a linha-guia formada por acentuações das 16 pulsações elementares segundo o princípio da imparidade rítmica. A audição do trecho nos revela quatro planos sonoros distintos. Por esta razão, no exemplo abaixo optou-se por uma escrita que destaca a distribuição em quatro camadas texturais, conforme é apresentado a seguir (Ex.13):

A relação de complementaridade entre as quatro camadas texturais, no exemplo acima, ocupa as 16 pulsações elementares, cujas acentuações formam na linha-guia um padrão rítmico característico do paradigma do Estácio: "(16) x . x . x . . x . x . x . . ". Este pode ser pensado como um desenvolvimento da linha-guia anterior " (8) . x . x . x " $(3+3+2)$, pela adição de dois grupos ternários e um binário $(2+3+3+3+2+3)$.

0 tratamento pianistico manipula quatro camadas texturais distintas onde cada uma assume conteúdos rítmicos e harmônicos específicos. Os baixos (Ex.13), que pontuam a primeira nota de cada tempo com as fundamentais dos acordes, ao se fundirem à voz superior, formam uma variação do padrão rítmico característico do maxixe, predominante no acompanhamento da mão esquerda dos pianeiros das primeiras décadas do século XX, como Ernesto Nazareth. Almeida se refere a essas estruturas como "baixo condutor harmônico", que acumulam em si a realização da linha do baixo, da harmonia e do ritmo (ALMEIDA, 1999, p.115).

Sendo assim, podemos verificar a sobreposição dos dois estilos de samba. Na mão direita, o samba novo é observado nas acentuações ímpares das 16 pulsações elementares que caracterizam o paradigma do Estácio ou ciclo do tamborim que, sob o ponto de vista da escrita ocidental, resulta em algum grau de contrametricidade. $\mathrm{Na}$ mão esquerda observa-se a manifestação do samba antigo através de estruturas características do maxixe, cujas variações rítmicas remetem ao paradigma do tresillo, que prevê acentuações ímpares no ciclo de 8 pulsações elementares. Sob o ponto de vista da escrita ocidental, este último é menos contramétrico que o anterior; um exemplo disso é o baixo (as notas mais graves), cujo padrão "(8) x . . . . . ." equivale a uma escrita totalmente cométrica segundo a lógica do compasso ${ }^{2} / 4^{\prime}$ como pode ser observado do c.42-47 (Ex.13).

A audição do exemplo nos revela que Cesar Camargo Mariano imprime diferentes durações às notas do baixo ao longo do trecho. Isso se deve ao fato de que as duas camadas texturais escritas na clave de fá mantêm o padrão intervalar de sétima (c.42), décima primeira e décima (c.43) a cada ciclo de dois compassos (Ex.13, 14 e 16). A mão esquerda, por alcançar a abertura de sétima com facilidade, permite que a nota do baixo tenha maior duração. 0 mesmo não ocorre com as aberturas dos intervalos de décima ou décima primeira que, para serem alcançadas pela mão esquerda, exigem que 0 pianista realize um movimento de "salto", o que por sua vez impede que a nota do baixo continue pressionada, resultando na curta duração destas notas. Este é um caso em que a escolha da disposição das notas dos acordes tem implicações diretas no ritmo, ou seja, a especificidade do conteúdo rítmico está relacionado com o conteúdo harmônico (montagem dos acordes) e, em torno desta relação, estão os limites impostos pela escrita pianística, isto é, do que é possivel realizar pianisticamente.

Ainda em relação ao conteúdo rítmico das camadas texturais, é importante pensarmos em sua organização ao longo das 16 pulsações elementares. A noção de interlocking ou relação de complementaridade, é pertinente para tal avaliação. Considerando que na segunda frase da seção $B$ ocorre uma repetição de um ciclo de dois compassos através de uma "transposição", a abordagem de um dos ciclos é suficiente. Tomemos como exemplo os c.42-43 (ex.14).

Na notação da resultante rítmica observa-se o nível de hierarquia das acentuações nas 16 pulsações elementares, cujas notas são indicadas pela linha pontilhada no Ex.14. Esta linha percorre o "caminho" das pulsações elementares

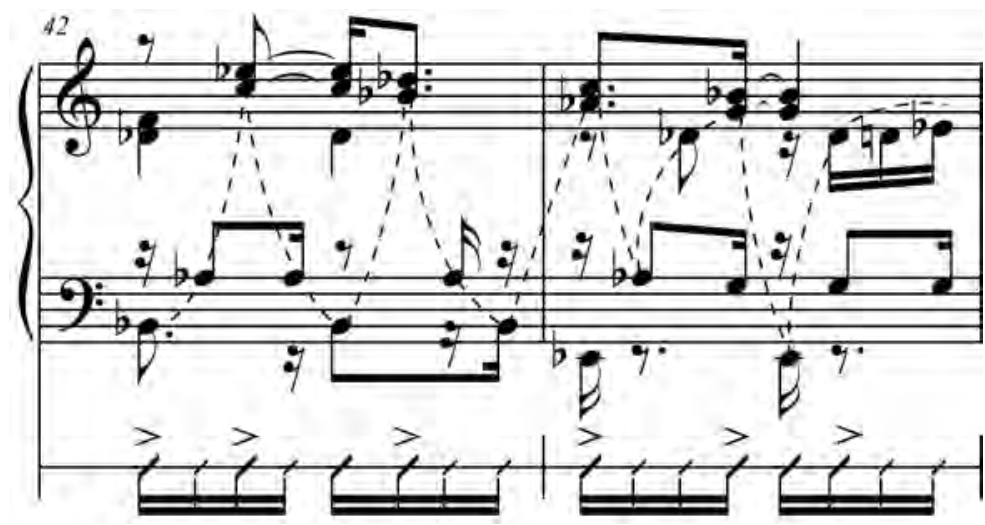

Ex.14 - Cristal, relação de complementaridade nos c.42-43. 


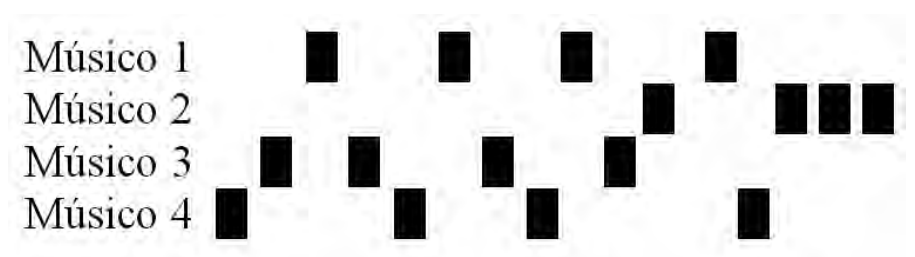

Ex.15 - Cristal, representação de interlocking na segunda frase da seção B.

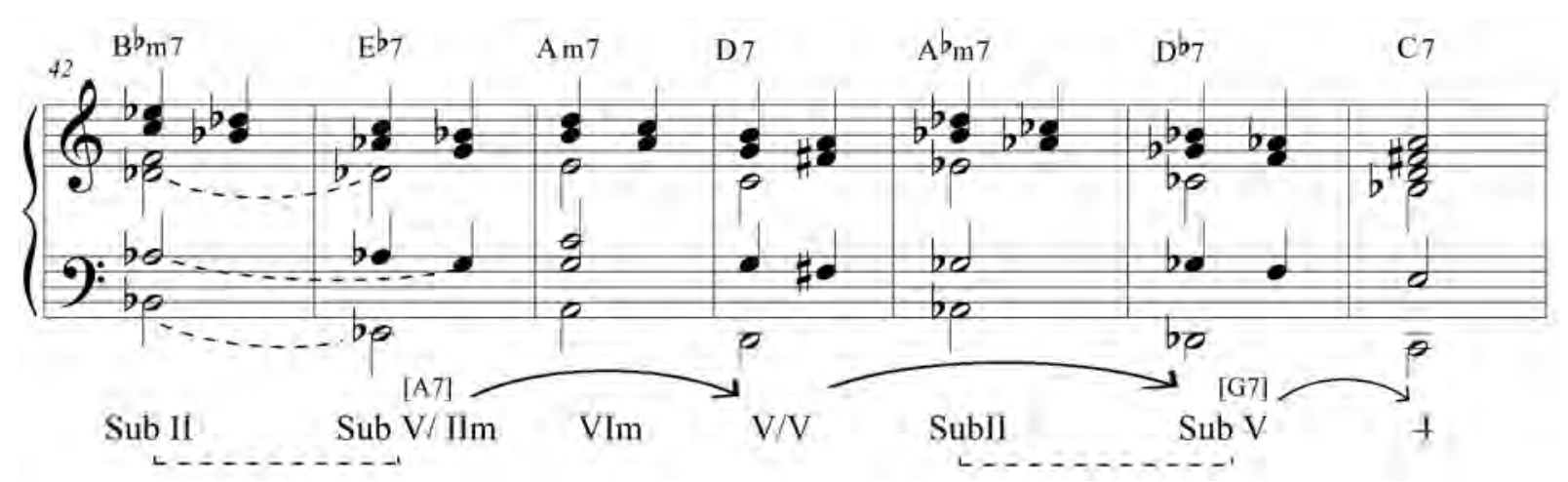

Ex.16 - Cristal, redução harmônica do c.42-49.

através da mão direita (clave de sol) e esquerda (clave de fá) do pianista; como são quatro planos sonoros, cada mão realiza duas camadas texturais.

Como mostra o Ex.14, as camadas texturais "cruzam" seus ritmos, e intercalam seus pulsos elementares, fenômeno este citado anteriormente por Oliveira Pinto, que se referia à "forma como a mão direita e a esquerda se complementam ao percutirem um tambor", onde os impactos de uma linha sonora se encaixam nos momentos vagos deixados pela outra. Fazendo uma apropriação do modelo gráfico proposto por Kubik para visualizar o interlocking ou relação de complementaridade entre diversos músicos, representados na escrita pianística por quatro camadas texturais, poderíamos representar o trecho da seguinte forma (Ex.15):

Diferentemente do exemplo de Kubik (Ex.8), a organização interna desse interlocking apresenta relativa irregularidade. Contudo, as três repetições deste ciclo durante a segunda frase da seção B caracterizam uma regularidade de ocorrência deste padrão.

Os arpejos dos c.48-49 (Ex.13) são uma manifestação do "motivo contramétrico", cujas notas são agrupadas por repetição, como mostram as ligaduras pontilhadas no Ex.14. Ao longo de toda a peça, Cesar Camargo Mariano utiliza arpejos para demarcar as seções.

Portanto, cada camada textural apresenta configurações rítmicas e harmônicas que, atuando em conjunto, podem ser comparadas a um mecanismo cujas peças e engrenagens obedecem aos princípios e limitações impostos pela condução de vozes, ritmo do samba e escrita pianística.

Nestes oito compassos da segunda frase da seção $B$, observa-se o aumento da densidade harmônica através um trecho modulante típico de uma harmonia de "ponte", onde a relação cromática entre os acordes afasta 0 vínculo com a tonalidade principal de Dó maior e segue em direção a uma nova região. Como pode ser observado no Ex.16, a relação cromática ocorre a cada ciclo de dois compassos, através de progressões [Sub IIm7-Sub V7] ${ }^{13}$ que alcançam o primeiro grau (mesmo que na forma de dominante) no acorde C7 no c.48.

A segunda frase da seção B é, portanto, caracterizada pelo aumento da densidade harmônica e textural, acompanhados de uma variedade de padrões rítmicos que manipulam na mesma textura, de forma complementar os paradigmas rítmicos do tresillo e do Estácio.

Terceira frase - seção rítmica, c.50-57

0 arpejo ascendente dos c.48-49 (Ex.13) marca a passagem para terceira frase da seção, que envolve os c.50-57 (Ex.17). Nesta frase, a organização textural é semelhante à verificada na seção de introdução, com triades na região média, baixo pedal na região supergrave que enfatiza a nota Dó bemol e "ataques" de tríades na região aguda. Porém, diferentemente da seção de introdução, temos aqui a afirmação do ritmo do samba através do tratamento pianístico que enfatiza o aspecto 


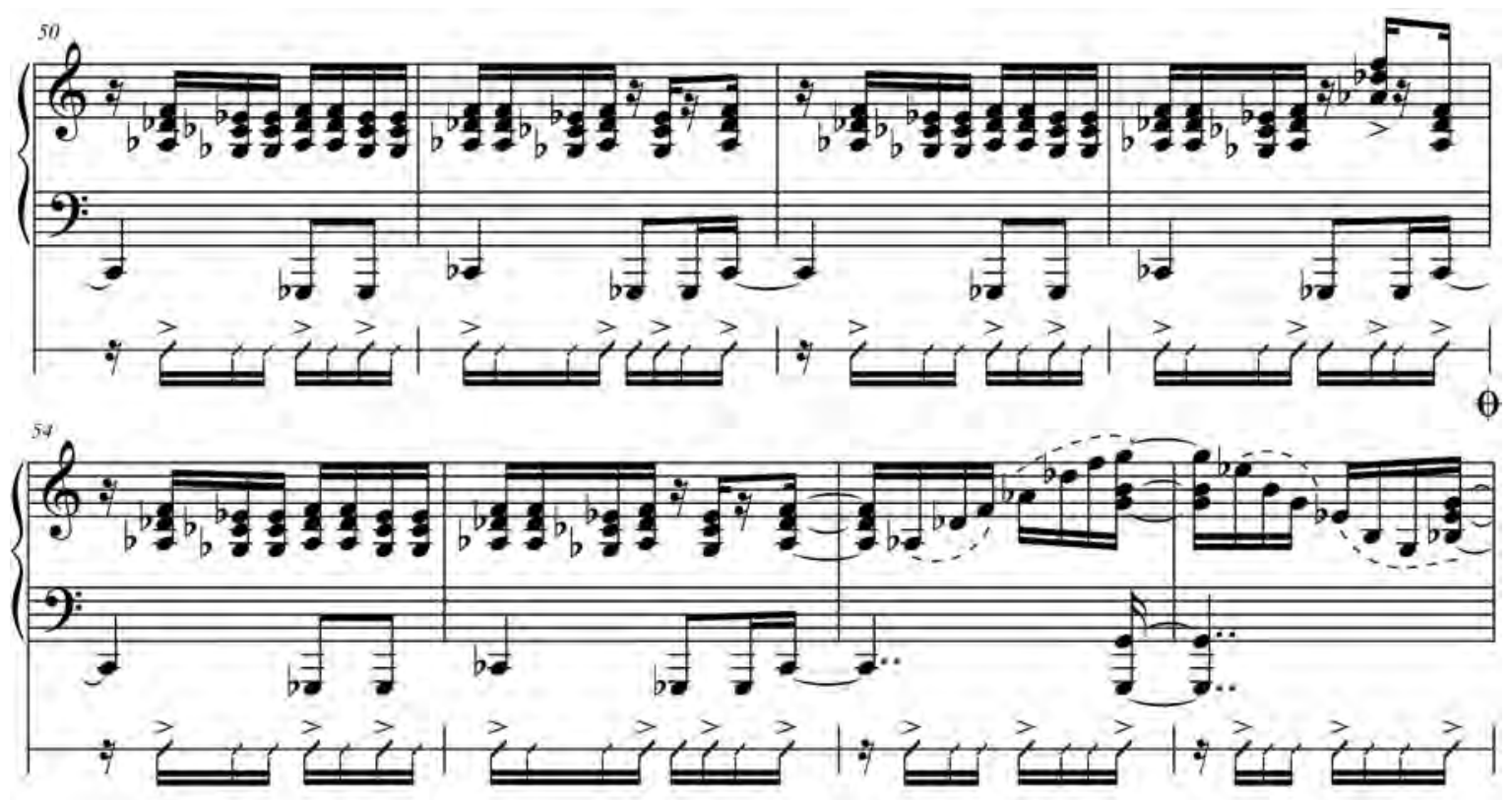

Ex.17 - Cristal, c.50-57, seção rítmica.

percussivo, cuja sonoridade (organização textural e toque stacatto) é análoga à sobreposição do tamborim na mão direita e ao tambor surdo na mão esquerda (Ex.17):

Assim como a segunda frase da seção $B$, a terceira frase é constituída por três repetições do ciclo do tamborim seguido de arpejos nos dois últimos compassos que preparam a chegada da nova seção. As acentuações das 16 pulsações elementares formam a linha-guia "(16) . $x$. . $x . x . x \ldots x . x . x^{\prime \prime}(3+2+2+3+2+2+2)$, que é sobreposta à marcação do tambor-surdo, cujo padrão rítmico é "(16) . . . . x. x . x . . x . x x" $(5+2+2+4+2+1) .0$ ciclo do tamborsurdo, que nos exemplos anteriores apresentava divisões pares, nesta passagem apresenta o princípio da imparidade rítmica, representada pela última semicolcheia do ciclo de dois compassos (Ex.17). Sendo assim, a marcação "antecipa" a articulação sonora do primeiro tempo para a semicolcheia anterior à barra de compasso.

A frase termina com arpejos que culminam em acordes nos c.56-57 (Ex.17). A linha-guia "(8) . x . . x . . x" surge das acentuações que consideram a repetição das notas e a ênfase dada aos arpejos, como mostram as linhas pontilhadas no Ex.18. Sendo o mesmo padrão rítmico que predomina na seção de introdução e na seção $A$, esta linha-guia já sugere o retorno a estas seções.

Nesta seção é possivel estabelecer relações que abrangem os níveis textural, harmônico e rítmico. Dentre os aspectos em que a dimensão harmônica relaciona-se com a dimensão rítmica, destacam-se dois. Primeiro, devido à ausência de uma linha melódica e por apresentar baixa movimentação harmônica, o aspecto rítmico sobressai em relação a esses parâmetros. Trata-se de um trecho essencialmente rítmico, onde o que está em jogo é o aspecto "corporal" da "batucada", dada pelo tamborim e pelo tambor-surdo, em detrimento do aspecto "racional" da construção melódica e da condução de vozes através das progressões harmônicas.

0 segundo aspecto diz respeito à região tonal onde ocorre a seção: Dó bemol. Enquanto a mão direita se alterna entre as tríades de Ré bemol maior e Dó bemol, os baixos realizam a fundamental e a quinta do acorde, numa relação intervalar de quarta justa que enfatiza o acorde de Dó bemol. 0 Ex.18 abaixo representa a redução harmônica da passagem:

A coleção de notas reunidas pelas tríades da mão direita sugerem o modo de Dó bemol lídio, - Dób, Réb, Mib, Fá, Solb, Láb - que caracteriza-se pela presença da quarta aumentada - nota fá natural (c.50-56, Ex.18). Portanto, esse trecho "essencialmente rítmico" ocorre em uma região harmônica muito específica, se comparado às outras seções.

Como vimos anteriormente, na seção de introdução é explorado o modo de Dó menor; a seção $A$ é apresentada em Dó maior (tonalidade principal); na seção $B$, é alcançada a região de Sol maior (dominante), onde inicia-se uma progressão cromática que, passando pelo acorde de Dó com sétima - entendido como um substituto da dominante do sétimo grau (SubV/VII,) -, realiza seu último passo cromático em direção ao modo de Dó bemol lídio (Ex.18).

Esta "seção rítmica" é apresentada, portanto, meio tom abaixo da tonalidade principal, região mediante da dominante (terceiro grau a partir da dominante Sol maior), num âmbito tonal de seis bemóis (considerando a nota si bemol como implícita), apresentando uma distância considerável em relação à tonalidade principal Dó maior, o que afasta o trecho 
das relações harmônicas mais próximas de Dó maior. Este isolamento numa região tonal distinta, somado à condição estática da harmonia modal - contrastante com as seções $A$ e $B$ - , são aspectos harmônicos que ajudam a enfatizar 0 aspecto essencialmente rítmico do trecho, colocando a "pura batucada" num lugar de destaque na forma musical.

Os arpejos dos c.56-57 (Ex.18) marcam o final da seção $B$ e a repetição da seção de introdução, através do acorde de Ré bemol com sétima no baixo (Sub V), que apresenta notas em comum com o acorde anterior, Dó bemol lídio, cujo intervalo de trítono que caracteriza o acorde dominante está presente nas notas Dó bemol e Fá. No c.57 temos o arpejo do acorde dominante da tonalidade principal, Sol com sétima, que se encontra incompleto (apenas com a fundamental, terça e décima terceira bemol) e prepara a volta para o modo de Dó menor.

Em suma, e metaforicamente, a seção B pode ser pensada como uma movimentação que parte de contexto musical clássico-romântico da primeira frase (c.34-42, Ex.12), em direção ao contexto musical atribuído à escola de samba através da "pura batucada" produzida pela sobreposição do tamborim ao tambor-surdo (c.50-57, Ex.17). A segunda frase representa a transição, o caminho a ser percorrido, onde já se pode ouvir o padrão do tamborim na mão direita, enquanto a mão esquerda trabalha com elementos próximos do maxixe, portanto ainda não realiza a marcação explícita do tambor-surdo (c.42-49, Ex.13).

As progressões harmônicas são fatores de movimentação, que conduzem a narrativa por diferentes "caminhos", representados pelas diversas regiões tonais. Saindo da escrita "europeia" em Sol maior, percorre o trecho "tortuoso" da segunda frase, um caminho harmônico acidentado e irregular, onde atenuam-se as referências de tonalidade, até chegar à terceira frase e fixar-se em um novo e inesperado local: o modo lídio de Dó bemol. Neste ponto, interrompe-se a movimentação das progressões harmônicas para se contemplar uma redução da bateria de escola de samba durante oito compassos.

\section{4 - Variação da seção $A$}

Nesta reexposição da seção $A$, ocorre uma variação que consiste na substituição da linha melódica principal por uma levada característica dos gêneros precursores do samba como polca-lundu, maxixe, tango brasileiro e outros, característicos do estilo antigo do samba.

Sendo Ernesto Nazareth uma influência declarada de Cesar Camargo Mariano, procurou-se em uma série de peças do músico carioca um trecho cuja escrita pianistica apresentasse a mesma construção rítmica e textural verificada em Cristal (Ex.20). Foram encontrados diversos exemplos, dentre os quais foi selecionado o trecho que abrange os c.68-72 do Tango Nenê (1895). Nos exemplos abaixo, pode-se observar o material referido:

A mão esquerda do c.68-72 de Nenê (Ex.19) e c.7374 de Cristal (Ex.20), apresentam um padrão rítmico (8) x...xx.x." (com pequena variação no c.72),semelhante à sincope característica que predomina na escrita para piano dos maxixes: "(8) x x . x x . x .". Este padrão é complementar à linha-guia observada na mão direita: "(8) . x . x . x . x",

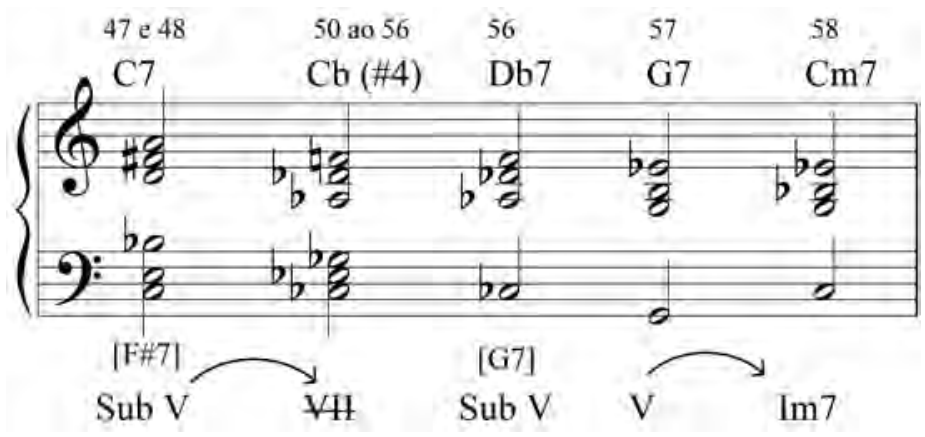

Ex.18 - Cristal, redução harmônica dos c.47-58.

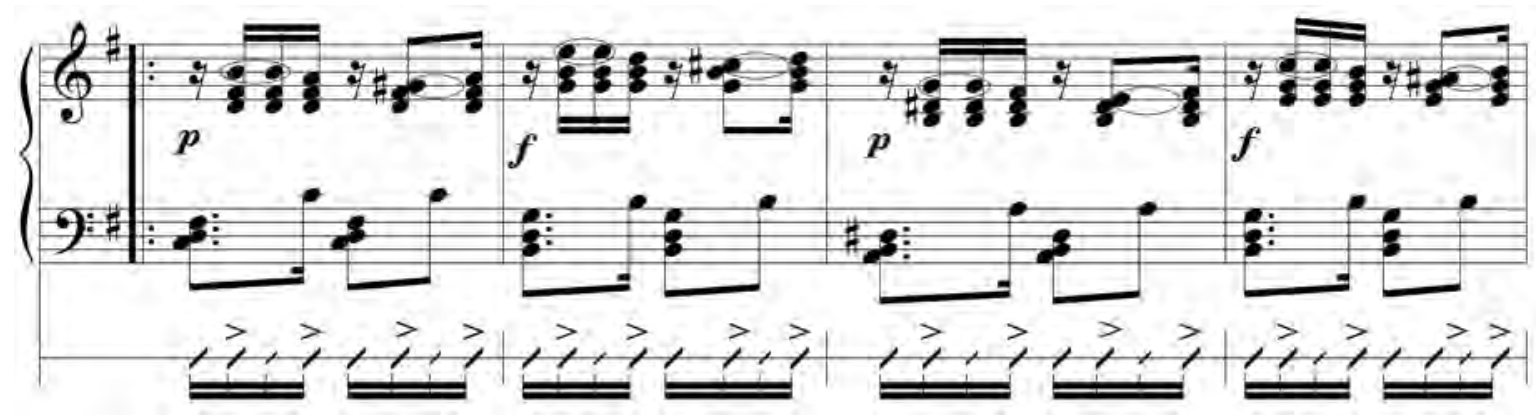

Ex.19 - Nenê, Ernesto Nazareth, c.68-71. 


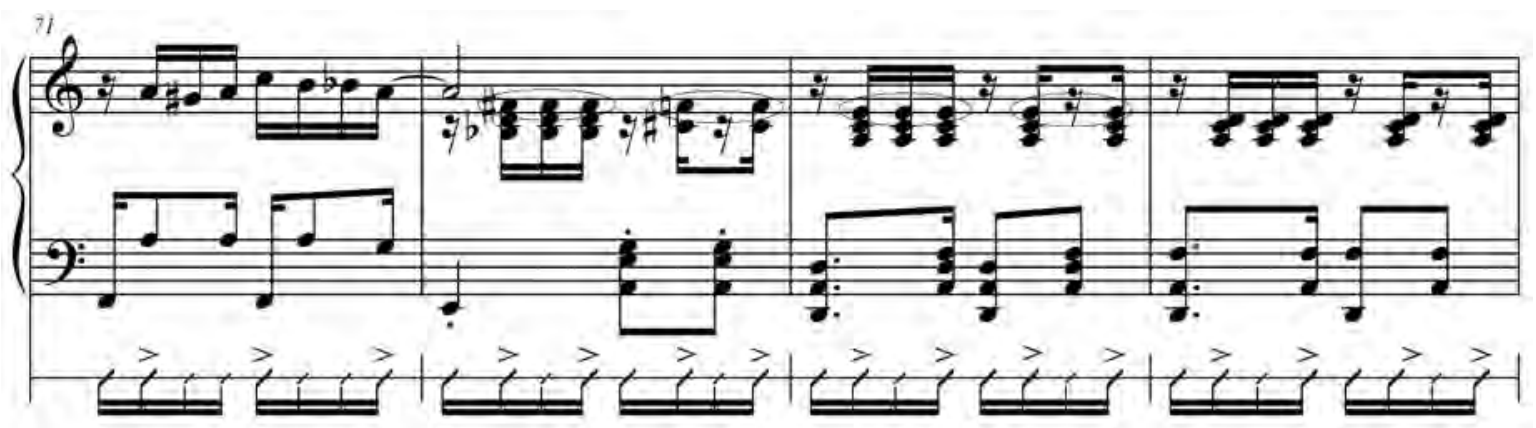

Ex.20 - Cristal, c.71-74.

padrão binário, que na escrita do compasso $2 / 4$ representa um alto grau de contrametricidade. As figurações rítmicas nos trechos abordados apresentam ciclos de 8 pulsações elementares e são variações do paradigma do tresillo.

Em relação ao aspecto harmônico, podemos verificar diferenças tanto na montagem dos acordes quanto no tratamento das tensões harmônicas. Como pode ser observado no Ex.16, Cesar Camargo Mariano distribui as notas dos acordes de forma complementar entre as camadas texturais, de modo que para obter o acorde completo (tétrade básica mais tensões), é necessário considerar todas as camadas verticalmente, pois os conteúdos harmônicos não são sobrepostos através de dobramentos ${ }^{14}$. Já na escrita de Ernesto Nazareth (Ex.19) o mesmo procedimento não é observado. Tendo o c.68 como exemplo, o baixo realiza a fundamental, terça e sétima do acorde D7 (respectivamente Ré, Fá\# e Dó).

Sendo assim, numa relação de complementaridade, sobrariam para as outras camadas texturais a quinta (nota lá) e as possíveis tensões do acorde. No entanto, fundamental e terça (notas Ré e Fá\#) são dobradas ou sobrepostas nos blocos de acordes da mão direita.

Outro aspecto relevante são as diferenças no tratamento das tensões. Em Ernesto Nazareth, as apojaturas produzem tensões nos acordes e são imediatamente resolvidas. A duração dessas tensões equivale a duas semicolcheias (como indicam os círculos no Ex.19). Cesar Camargo Mariano, por sua vez, conduz os acordes de modo a valorizar as tensões, que como indicam os círculos no Ex.20, tem duração de até um compasso. Esta valorização das tensões também está relacionada com a montagem dos acordes em posição fundamental, e como observa Santos, "diferentemente do choro tradicional, os acordes utilizados no jazz aparecem em sua maioria na posição fundamental, para que as tensões existentes soem como tal." (SANTOS, 2002, p.11)

\section{5 - Conclusão}

A partir do presente estudo, é possivel considerar que Cristal sintetiza alguns pilares da formação musical de Cesar Camargo Mariano: sua infância, cujo ambiente musical familiar lhe proporcionou o contato com a música de Ernesto Nazareth e o convívio como espectador atento nas rodas de choro, influências que podem ser observadas na seção A. Sua fase de "jazzista radical", que segundo o próprio artista, foi influenciada pelos trios de pianistas de jazz, verificada no tratamento harmônico, que avança sobre regiões tonais distantes da tonalidade principal e enfatiza as tensões dos acordes. Influência da música erudita, que pode ser observada na primeira frase da seção $B$, com a escrita "clássicoromântica". Seu contato com o samba, na terceira frase da seção $B$ e, por último, a influência da música pop, funk ou fusion em sua "fase eletrônica" dos sintetizadores, na seção de introdução.

Considerando a alta ocorrência de progressões de substitutos da dominante verificados no Ex.17, podese considerar a "linguagem harmônica" ou "contexto harmônico" praticado por Cesar Camargo Mariano como, segundo Sérgio Freitas, pertencente aos

[...] setores da música popular que, ora mais, ora menos, são reconhecidos como 'modernos' e 'dissonantes' (ou seja, setores do jazz, da bossa nova, da MPB, do samba-jazz, etc.) que, abraçando sonoridades mais tortuosas, elegeram o "SubV7" como uma constante estilistica favorita" (FREITAS, 2010, p.196).

Pode-se incluir nesse contexto a chamada Música Popular Brasileira Instrumental (MPBI) que dialoga com uma série de influências e musicalidades através da manipulação de uma variedade de gêneros, ritmos e estilos que são dispostos lado a lado ou mesmo sobrepostos no discurso musical. Tal fenômeno se verifica em Cristal.

A semelhança com a música dos chamados pianeiros pode ser observada no tratamento rítmico e textural da obra, que mantém o fluxo sonoro das pulsações elementares, cujas acentuações constituem as linhas-guia. Esta se mantém relativamente estável ao longo de toda a peça e manifesta-se em diversas camadas texturais, mesmo apesar de mudanças na textura. A manutenção da estabilidade da linha-guia, com seus padrões rítmicos cíclicos e constantes, é fator que vincula o samba para piano de Cesar Camargo Mariano ao samba para piano dos chamados pianeiros. 


\section{Referências}

ALMEIDA, Alexandre Zamith. Verde e amarelo em preto e branco: as impressões do choro no piano brasileiro. Campinas: Instituto de Artes, Universidade de Campinas, 1999. Dissertação (Mestrado em Música).

BOLÃO, Oscar. A percussão na música do Rio de Janeiro. Luminar: 2003.

BRAGA, Leandro. Primeira Dama: A música de Dona Ivone Lara. Rio de Janeiro: Gryphus, 2003.

CIRINO, Giovani. Narrativas musicais: performance e experiência na música popular instrumental brasileira. São Paulo: Annablume/ Fapesp, 2009.

DOURADO, Henrique Autran. Dicionário de termos e expressões da música. São Paulo: Editora 34, 2004.

FAOUR, Paula. Acompanhamento pianístico em Bossa Nova: análise ritmica em duas performances de João Donato e Cesar Camargo Mariano. Rio de Janeiro: Universidade Federal do Estado do Rio de Janeiro, 2006 (Dissertação de mestrado).

FREITAS, Sérgio Paulo Ribeiro de. Que acorde ponho aqui? Harmonia, práticas teóricas e o estudo de planos tonais em música popular. UNICAMP, Campinas, 2010 (Tese de doutorado).

GOMES, Marcelo Silva. Samba-Jazz aquém e além da Bossa Nova : três arranjos para Céu e Mar de Johnny Alf. UNICAMP, Campinas, 2010. (Tese de doutorado).

GOMES, Rafael Tomazoni. O samba para piano solo de Cesar Camargo Mariano. Florianópolis: Universidade do Estado de Santa Catarina, 2012 (Dissertação de mestrado).

GRIDLEY, Mark C. Jazz Styles: history and analysis. Englewood Cliffs: Prentice Hall, 2005.

MACHADO, Cacá. $O$ enigma do homem célebre: ambição e vocação de Ernesto Nazareth. São Paulo: Instituto Moreira Salles, 2007.

MARIANO, Cesar Camargo. Solo: Cesar Camargo Mariano - memórias. São Paulo: Leya, 2011.

Cesar Camargo Mariano - Solo Brasileiro. CD 518874-2. PolyGram, 1994.

OLIVEIRA PINTO, Tiago de. As cores do som: Estruturas sonoras e concepção estética na música afro-brasieira. África Revista do Centro de Estudos Africanos. v.22-23. São Paulo: 2001.

PIEDADE, Acácio Tadeu. Jazz, música brasileira e fricção de musicalidades. Opus. v.11. 2005.

SANTOS, Rafael dos. Análise e considerações sobre a execução dos choros Canhoto e Manhosamente de Radamés Gnattali. Per Musi, v.3. Belo Horizonte: UFMG, 2002. p.5-16.

SANDRONI, Carlos. Feitiço Decente: transformações do samba no Rio de Janeiro, 1917-1933. Rio de Janeiro: Jorge Zahar Ed.: Ed. UFRJ, 2001.

SARAIVA, Joana Martins. A invenção do samba jazz: discursos sobre a cena musical de Copacabana no final dos anos de 1950 e inícios dos anos 1960. Rio de Janeiro: Pontifícia Universidade Católica, 2007 (Dissertação de mestrado).

TAGG, Philip. Everyday Tonality: Towards a tonal theory of what most people hear. The mass media music scholars press: New York \&t Montréal: 2009.

TINHORÃO, José Ramos. Os sons que vêm da rua. Editora 34, São Paulo: 2005 [1976].

Pequena história da música popular: da modinha à canção de protesto. Vozes, RJ: 1974.

\section{Notas}

1 Para maiores esclarecimentos sobre a utilização do termo pianeiro pela presente pesquisa, ver G0MES (2012, p.13-26).

2 Para mais exemplos da presença do piano no contexto de baile, bem como um estudo de aspectos que relacionam o piano e o samba, ver GOMES (2012).

3 A partitura integral está disponivel em http://www.ernestonazareth.com.br/pdfs/atrevidinha.pdf, acessado em 28/06/2012.

4 No presente estudo, considera-se que as noções de choro e samba são imbricadas. Por uma questão metodológica, o emprego da palavra samba ganha um significado abrangente. Entende-se samba como uma variedade de gêneros, que vão desde os gêneros precursores do samba como a polca-lundu, o maxixe, o tango brasileiro, o choro, até as manifestações "modernas" do gênero, como a bossa-nova e o samba-jazz.

5 Entrevista concedida à rádio UOL, disponivel em http://www.radio.uol.com.br/\#/programa/uol-that-jazz/edicao/9055862, acessado em 10/02/2012.

60 pianista Dick Hyman descreve aspectos do estilo pianístico de Erroll Garner no vídeo intitulado "Errol Garner Lesson 1 - Dick Hyman" , disponível em http://www.youtube.com/watch?v=IM-77RvpJf0 (acessado em 10/02/2012), parte integrante do CD-Rom "Century Of Jazz Piano Encyclopedy" (1999).

7 Transcrição disponivel em http://www.youtube.com/watch?v=i1RokAJ0qAc, acessado em 10/05/2012.

8 ANDRADE, Mario de. As melodias do boi e outras peças, São Paulo, Martins, 1987, p.397, 409, 416 (citado por SANDRONI, 2001, p.23).

9 MUKUNA, Kazadi Wa. Contribuição bantu na música popular brasileira, São Paulo, Global, s/d. (citado por SANDRONI, 2001, p.25)

10 Segundo Dourado (2004, p.147), a nota fantasma (ghost note) refere-se a um som abafado e pouco distinto, de caráter percussivo.

11 Disponivel em http://www.cesarcamargomariano.com/pgcatalogport.html, acessado em 10/05/2012. 
12 "Pequena sequência repetida de (quase sempre), três ou quatro acordes" (TAGG, 2009, p.280).

13 Para mais detalhes sobre a análise harmônica do trecho referido, ver GOMES (2012, p.91).

14 Cada camada textural assume um conteúdo harmônico especifico. Por exemplo, se o baixo realiza fundamental e terça do acorde, o acompanhamento não incluirá estas notas, evitando assim o dobramento.

Rafael Tomazoni Gomes é bacharel em piano pela Universidade do Estado de Santa Catarina (UDESC) e mestre em musicologia/etnomusicologia pela mesma universidade, onde defendeu a dissertação "0 samba para piano solo de Cesar Camargo Mariano". Tem ministrado workshops em cursos de graduação em música no estado de Santa Catarina com intuito de divulgar seu trabalho teórico. Como instrumentista, atua como solista, interpretando peças que foram objeto de seu estudo teórico e outras, e em grupos de música popular na cidade de Florianópolis.

Guilherme Antonio Sauerbronn de Barros é bacharel em piano pela Universidade Federal do Estado do Rio de Janeiro (UNIRIO), mestre em música - piano pela Universidade Federal do Rio de Janeiro (UFRJ) e doutor em musicologia pela UNIRIO. Foi premiado em concursos nacionais de piano e participou como executante de inúmeros master-classes. Tem artigos publicados em revistas especializadas e anais de eventos da área de musicologia. Desenvolve pesquisa nas áreas de estética, análise e educação musical e tem priorizado em seus estudos a relação da música com a filosofia e a literatura, em particular no idealismo e no romantismo alemão dos séculos XVIII e XIX. Atualmente, dedica-se ao estudo dos fundamentos teóricos de técnicas avançadas de análise musical. Como instrumentista, tem atuado como solista $\mathrm{e}_{\mathrm{1}}$ principalmente, como camerista. Sua atividade docente inclui, além de piano, análise musical e musicalização infantil. 